\author{
Monika Frontczak, Beata Olas \\ Katedra Biochemii Ogólnej \\ Instytut Biochemii \\ Wydział Biologii i Ochrony Środowiska \\ Uniwersytet Łódzki \\ Pomorska 141/143, 90-236 Łódź \\ E-mail: frontczak.m@wp.pl
}

\title{
MIÓD I JEGO SKŁADNIKI CHEMICZNE - ROLA W PROFILAKTYCE I LECZENIU CHORÓB UKŁADU KRĄŻENIA
}

\section{WPROWADZENIE}

Miód jest słodkim produktem naturalnym, wytwarzanym przez pszczoły (Apis mellifera) $z$ nektaru roślinnego i spadzi, cenionym przez ludzi od wielu lat ze względu na wysoka wartość odżywcza i pozytywny wpływ na zdrowie (ALVAREZ-SUAREZ i współaut. 2014). Skład, kolor, aromat, smak i konsystencja miodu sa zmienne i zależą głównie od jego pochodzenia kwiatowego, czynników środowiskowych oraz sposobu jego przetwarzania i przechowywania, ponieważ podczas przegrzania lub długiego przechowywania może wytworzyć się lotny i, zależnie od stężenia, toksyczny 5-hydroksymetylofurfural (TORNUK i współaut. 2013, KHAN i współaut. 2017).

\section{SKEAD CHEMICZNY MIODU PSZCZELEGO}

Naturalny miód składa się $\mathrm{z}$ wielu różnych zwiazków, do których należa m.in. woda, cukry, wolne aminokwasy, białka, minerały, witaminy i różne zwiąki fitochemiczne (Tabela 1) (CIANCIOSI i współaut. 2018).

Głównym składnikiem miodu, stanowiącym około 95\% suchej masy, sa węglowodany (BogDANov i współaut. 2008, CiAnciosi i współaut. 2018). Odpowiadają one za właściwości fizykochemiczne miodu, do których zalicza się lepkość, higroskopijność i granulację (CAVIA i współaut. 2002). W prawie wszystkich rodzajach miodu dominującymi cukrami są fruktoza i glukoza, których stężenie i stosunek jest wskaźnikiem w klasy- fikacji miodów jednokwiatowych. W małych stężeniach obecne sa również disacharydy, trisacharydy i oligosacharydy (KAŠKONIENE i współaut. 2010).

Miód zawiera niewiele białek, aminokwasów i enzymów, które pochodzą $z$ różnych źródeł, takich jak nektar, ślina i wydzielina gruczołów gardłowych pszczół miodnych. Najważniejszymi enzymami są: trawiąca skrobię diastaza, inwertaza, która rozkłada sacharoze na glukozę i fruktozę, oraz oksydaza glukozowa odpowiedzialna za przekształcenie glukozy w $\delta$-glukonolakton, który jest następnie hydrolizowany do kwasu glukunowego (BogdANOv i współaut. 2008, SAK-BOSNAR i SAKAČ 2012).

Równie ważnym składnikiem miodu, choć występującym w minimalnej ilości wynoszącej około $0,5 \%$, sa kwasy organiczne, które powstaja $z$ cukrów dzięki enzymom wydzielanym przez pszczoły podczas przekształcania nektaru w miód lub sa pozyskiwane bezpośrednio $z$ nektaru. Charakteryzuja się działaniem przeciwbakteryjnym i przeciwutleniajacym oraz odpowiadaja za kolor i smak miodu, a także za jego właściwości fizyczne, takie jak: pH, kwasowość i przewodność elektryczna (CHERI i współaut. 1994, MATO i współaut. 2006).

$\mathrm{Na}$ kolor, krystalizację, lepkość, smak i gęstość wpływa natomiast zawartość wody $\mathrm{w}$ miodzie. Wilgotność miodu jest zwiazana m.in. $z$ jego pochodzeniem botanicznym i wynosi zazwyczaj od $13 \%$ do $25 \%$, a optymalna wartość to $17 \%$. Naturalna wysoka zawartością wody charakteryzuje się miód 
Tabela 1. Skład chemiczny najczęściej spożywanego miodu (CiANCIOsı i współaut. 2018).

\begin{tabular}{ll}
\hline Składnik & Średnia ilość w $100 \mathrm{~g}$ miodu \\
\hline Woda & $16,9-18 \mathrm{~g}$ \\
Węglowodany (ogółem) & $64,9-73,1 \mathrm{~g}$ \\
Fruktoza & $35,6-41,8 \mathrm{~g}$ \\
Glukoza & $25,4-28,1 \mathrm{~g}$ \\
Maltoza & $1,8-2,7 \mathrm{~g}$ \\
Sacharoza & $0,23-1,21 \mathrm{~g}$ \\
Białka, witaminy, aminokwasy i sole mineralne & $0,5-1 \mathrm{~g}$ \\
\hline
\end{tabular}

wrzosowy i koniczynowy (MACHADO DE-MELO i współaut. 2018).

W miodzie obecne są także różne ilości minerałów, a ich zawartość zależy przede wszystkim od jego pochodzenia botanicznego i wynosi od $0,04 \%$ w miodach jasnych, do $0,2 \% \mathrm{w}$ miodach ciemnych (MISSIO DA SILVA i współaut. 2016). W miodzie występują również makro- i mikroelementy, pełniace podstawowa funkcję w układach biologicznych, zapewniajac prawidłowe działanie systemu krążenia, działając jako katalizatory w reakcjach biologicznych, utrzymując prawidłowe reakcje fizjologiczne i pobudzajac ogólny metabolizm (ALQARNI i współaut. 2014).

Niewielkie ilości witamin $z$ kompleksu B pochodza $z$ ziaren pyłku, który jest obecny w zawiesinie. W większości miodów występuje witamina $\mathrm{C}$, która nie rozpada się ze względu na niskie $\mathrm{pH}$ miodu, ale jest bardzo wrażliwa na utlenianie chemiczne i enzymatyczne, przyspieszane przez światło, tlen i ciepło (LEÓN-RUIZ i współaut. 2013, MISSIO DA SILVA i współaut. 2016). Kwas askorbinowy może być utleniany także przez nadtlenek wodoru wytwarzany przez oksydaze glukozową (CiUlu i współaut. 2011).

Ponadto, w miodzie wykazano obecność około 30 rodzajów zwiąków fenolowych, których profil zależy od różnych czynników, takich jak źródło botaniczne i geograficzne kwiatów oraz warunki klimatyczne. Sa one syntetyzowane $\mathrm{w}$ celu ochrony przed stresem biotycznym i abiotycznym oraz przed uszkodzeniami oksydacyjnymi (SANTOS-BUELGA i GONZÁLEZ-PARAMẤS 2017, CIANCIOSI i współaut. 2018, OlAs 2020). Moga mieć także korzystne działanie $w$ profilaktyce i leczeniu chorób sercowo-naczyniowych, ponieważ charakteryzują się właściwościami przeciwutleniajacymi, przeciwpłytkowymi i wazorelaksacyjnymi (OLAS 2020). Flawonoidy, podobnie jak inne przeciwutleniacze, bezpośrednio wychwytuja reaktywne formy tlenu, jednocześnie hamujacc aktywność enzymów odpowiedzialnych za wytwarzanie rodników ponadtlenkowych, chelatując metale przejściowe zaangażowane w procesy tworzenia rodników oraz zapobiegając procesowi peroksydacji poprzez redukcję rodników alkoksylowych i nadtlenkowych (PYRZYNSKA i BIESAGA 2009). Miód o ciemniejszym kolorze zawiera większe ilości związów bioaktywnych niż miód jaśniejszy, a tym samym ma wyższą zdolność przeciwutleniajacca. Ta różnica wynika $z$ różnych źródeł zbioru pyłku (PYRZYNSKA i BIESAGA 2009, JiBRIL i współaut 2019).

\section{CHARAKTERYSTYKA WYBRANYCH CHORÓB UKEADU KRĄŻENIA}

Choroby układu krążenia są główna przyczyna zgonów na całym świecie. Jedna $z$ najczęstszych chorób jest miażdżyca tętnic - przewlekła choroba zapalna, obejmujacca aorty i średnie tętnice, wewnątrz których tworza się bogatopłytkowe zakrzepy, prowadzace do ich zwężenia lub całkowitego zamknięcie światła. Pierwszym stadium choroby sa „pasma tłuszczowe” powstające na wewnętrznej powierzchni naczynia krwionośnego (BERESEWICZ i SKIERCZYŃSKA 2006, WALLACE 2011, SCHAFTENAAR i współaut 2016). Zmiany miażdżycowe w tętnicach wieńcowych, zaopatrujących mięsień serca w krew, sa główna przyczyna wystapienia choroby niedokrwiennej serca, zwanej również chorobą wieńcową. Odpowiada ona za największą liczbę zgonów $z$ przyczyn kardiologicznych, a zapadaja na nia nie tylko osoby starsze, ale również ludzie młodzi (ZIÓŁKOWSKI i współaut. 2009, MAROSZYŃSKA-DMOCH i WOŻAKOWSKA-KAPŁON 2014). Chorobą zwiększajaca ryzyko wystapienia udaru, zawału mięśnia sercowego oraz niewydolności serca jest nadciśnienie tętnicze, które należy do najczęściej występujacych chorób w kra- 
jach rozwiniętych. Obniżajac ciśnienie tętnicze można znaczaco zredukować możliwość wystapienia tych chorób, co ma największe znaczenie $\mathrm{w}$ ich prewencji. Udar mózgu jest trzecia najczęstsza przyczyną zgonów na świecie i najczęstsza przyczyną inwalidztwa u osób, które ukończyły 40 lat, a ryzyko jego wystapienia wzrasta liniowo wraz ze wzrostem ciśnienia tętniczego (NABEL 2003, CZARNECKA i ZABOJSZCZ 2004).

\section{MIÓD W DIECIE A CHOROBY UKŁADU KRĄŻENIA}

Dieta pełni istotna rolę $\mathrm{w}$ profilaktyce chorób układu krążenia, a miód powinno się traktować raczej jako suplement diety niż pełnowartościowy posiłek. Dawka $20 \mathrm{~g}$ miodu może zaspokoić około 3\% dziennego zapotrzebowania na energię, a zawarta $\mathrm{w}$ nim glukoza i fruktoza moga zostać wykorzystane jako natychmiastowe źródło energii zaraz po strawieniu (KHAN i współaut. 2017).

$\mathrm{Na}$ profilaktykę chorób układu krążenia pozytywnie wpływaja zawarte $\mathrm{w}$ miodzie zwiazki fenolowe, majace działanie przeciwzakrzepowe, przeciwniedokrwienne, przeciwutleniające i wazorelaksacyjne. Ma to szczególne znaczenie w przypadku choroby niedokrwiennej serca, ponieważ działanie flawonoidów obejmuje rozszerzenie naczyń wieńcowych, zmniejszenie aktywacji płytek krwi oraz zapobieganie utlenianiu lipoprotein o niskiej gęstości (LDL) (KHALIL i SUlAIMAN 2010, Olas 2020). Zauważono również, że regularne spożywanie miodu obniża poziom cholesterolu całkowitego, triglicerydów i LDL, natomiast podwyższa stężenie frakcji lipoprotein o wysokiej gęstości (HDL). Tlenek azotu, znajdujący się $\mathrm{w}$ dużej ilości w świeżych i ciemnych miodach, dzięki właściwościom wazodylatacyjnym również obniża ciśnienie krwi (KoszowsKa i współaut. 2013).

Łagodne działanie moczopędne miodu lipowego powoduje zmniejszenie obrzęków i obniżenie ciśnienia krwi, a zawartość olejków eterycznych pomaga w redukcji stresu i działa rozkurczajaco. Natomiast spożywanie miodu gryczanego zapobiega pękaniu naczyń krwionośnych, powstawaniu wybroczyn i wylewów dzięki poprawie elastyczności, wytrzymałości i przepuszczalności ścian naczyń włosowatych. Miód rzepakowy jest bogaty w glukoze i fruktozę, dzięki czemu wspomaga pracę mięśnia sercowego, zwiększając potencjał jego skurczu, co przekłada się na lepsze dotlenienie serca oraz wspomaga regeneracje organizmu. Redukuje również obrzęki spowodowane gromadzeniem się wody w tkankach oraz, tak jak miód gryczany, reguluje ciśnienie tętnicze i hamuje procesy miażdżycowe (BAKKOWSKA i JANDA 2018).
Badanie przeprowadzone przez YAGHOOBI i współaut. (2008) na osobach $z$ nadwaga $i$ otyłościa wykazało, że spożywanie naturalnego miodu w dawce 70 g przez 30 dni spowodowało u nich lekkie zmniejszenie masy ciała $(1,3 \%)$ i tkanki tłuszczowej $(1,1 \%)$. Ponadto, obniżył się też poziom całkowitego cholesterolu (3\%), LDL-C $(5,8)$, triacylogliceroli $(11 \%)$, poziom glukozy we krwi na czczo (FBG) $(4,2 \%)$ i białka C-reaktywnego (CRP) $(3,2 \%$, a u osób $z$ prawidłowymi wartościami zwiększył się poziom HDL-C (3,3\%). U pacjentów z podwyższonymi wartościami całkowitego cholesterolu, LDL-C, triacylogliceroli i CRP, spożycie miodu spowodowało obniżenie całkowitego cholesterolu o 3,3\%, LDL-C o $4,3 \%$, triacylogliceroli o $19 \%$, a CRP o $3,3 \%$ $(\mathrm{p}<0,05)$. Na tej podstawie badacze doszli do wniosku, że spożywanie naturalnego miodu zmniejsza ryzyko wystapienia choroby sercowo-naczyniowej, szczególnie u osób $z$ grupy ryzyka oraz nie powoduje zwiększenia masy ciała u osób zmagajacych się $z$ nadwaga lub otyłością.

\section{PODSUMOWANIE}

Miód posiada wiele zastosowań i jest powszechnie cenionym produktem naturalnym, wykorzystywanym przez ludzi od setek lat. Stosowany w umiarze, zmniejsza ryzyko wystapienia chorób układu krążenia i chorób cywilizacyjnych, jednocześnie nie wywołując efektów ubocznych.

$$
\text { Streszczenie }
$$

Miód to słodki produkt naturalny, wytwarzany przez pszczoły. Jego skład zależy od wielu czynników, jednak dominującymi cukrami pozostaja glukoza i fruktoza, odpowiadające za właściwości fizykochemiczne. Jest też bogatym źródłem związków fenolowych, korzystnie wpływających na zdrowie. Powinien być stosowany jedynie jako uzupełnienie zbilansowanej diety, która pełni ważna rolę w profilaktyce chorób układu krążenia. W zależności od rodzaju miodu, składniki w nim zawarte wpływają na różne parametry odpowiedzialne za rozwój chorób układu kraż̇enia.

\section{LITERATURA}

AlQARni A. S., OWAYss A. A., Mahmoud A. A., HANNAN M. A., 2014. Mineral content and physical properties of local and imported honeys in Saudi Arabia. J. Saudi Chem. Soc. 18, 618-625.

ALVAREZ-SUAREZ J. M., GASPARRINI M., FORBES-HERNÁNDEZ T. Y., MAZZONI L., GiAMPIERI F., 2014. The composition and biological activity of honey: a focus on manuka honey. Foods 3, 420-432.

BAKOWSKA M., JANDA K., 2018. Właściwości prozdrowotne wybranych miodów. Pomeranian J. Life Sci. 64, 147-151.

BERESEWICZ A., SKIERCZYŃSKA A., 2006. Miażdżyca - choroba całego życia $i$ całej populacji krajów 
cywilizacji zachodniej. Choroby Serca i Naczyń 3, 1-6.

BogdANOV S., JuREndic T., Sieber R., GallmanN P., 2008. Honey for nutrition and health: a review. Am. J. College Nutrit. 27, 677-689.

CAVIA M. M., FERNÂNDEZ-MUIÑO M. A., GÖMEZ-Alonso E., MONTES-PÉreZ M. J., HuidoBRO J. F., SANCHO M. T., 2002. Evolution of fructose and glucose in honey over one year: influence of induced granulation. Food Chem. 78, 157-161.

Cheri A., Spanedda L., Tuberoso C., Cabras P., 1994. Solid-phase extraction and high-performance liquid chromatographic determination of organic acids in honey. J. Chromatography A, 669, 59-64.

CiAnCIOSI D., Forbes-HERnÁNDEZ T. Y., AFrin S., GASPARRINI M., REBOREDO-RodRIGUEZ P., MANNA P. P., ZHANG J., LAMAS L. B., FLÓREZ S. M., Toyos P. A., Quiles J. L., GiAMPIERI F., BATTINO M., 2018. Phenolic compounds in honey and their associated health benefits: a review. Molecules 23, 2322-2341.

Ciulu M., Solinas S., Floris I., Panzanelli A., PilO M. I., PIU P. C., SPANO N., SANNA G., 2011. RP-HPLC determination of water-soluble vitamins in honey. Talanta 83, 924-929.

CZARNECKA D., ZABOJSZCZ M., 2004. Nadciśnienie tętnicze a udar mózgu. Choroby Serca i Naczyń 1, 19-25.

JibRIL F. I., HiLMi A. B. M., MANIVANNAN L., 2019. Isolation and characterization of polyphenols in natural honey for the treatment of human diseases. Bull. Nat. Res. Centre 43, 4-12.

KAŠKONIENĖ V., VENSKUTONIS P. R., ČEKSTERYTE V. 2010. Carbohydrate composition and electrical conductivity of different origin honeys from Lithuania. Food Sci. Technol. 43, 801-807.

KHALIL M. I., SUlAIMAN S. A., 2010. The potential role of honey and its polyphenols in preventing heart diseases: a review. Afr. J. Tradi. Complement. Alternat. Med. 7, 315-321.

KHAN R. U., NAZ S., ABUdABOS A. M., 2017. Towards a better understanding of the therapeutic applications and corresponding mechanisms of action honey. Environ. Sci. Pollut. Res. 24, 27755-27766.

Koszowska A., DitTFeld A., NOWAK J., ZiORA K., 2013. Pszczoły $i$ ich produkty - znaczenie dla zrównoważonego rozwoju roślin, zwierzat $i$ ludzi. Medycyna Srodowiskowa 16, 79-84.

LEÓN-Ruiz V., VERA S., GONZÁleZ-PORTO A. V. ANDRÉS M. P. S., 2013. Analysis of water-sol uble vitamins in honey by isocratic RP-HPLC. Food Analyt. Methods 6, 488-496.

Machado De-Melo A. A., Bicudo De Almeida-MuRadian L., SANCho M. T., Pascual-Maté A., 2018. Composition and properties of Apis mellifera honey: a review. J. Apicult. Res. 57, 5-37.
MAROSZYŃSKA-DMOCH E. M., WOŻAKOWSKA-KAPŁON B., 2014. Choroba wieńcowa $w$ populacji młodych dorosłych: skala problemu, czynniki ryzyka $i$ rokowanie - przeglad literatury. Folia Cardiol. 8, 267-274.

Mato I., Huidobro J. F., Simal-Lozano J., SANCHO M. T., 2006. Rapid determination of nonaromatic organic acids in honey by capillary zone electrophoresis with direct ultraviolet Detection. J. Agricult. Food Chem. 54, 15411550.

Missio Da Silva P., Gauche C., Gonzaga L. V., Costa A. C. O., FetT R., 2016. Honey: Chemical composition, stability and authenticity. Food Chem. 196, 309-323.

NABEL E. G., 2003. Cardiovascular disease. New Engl. J. Med. 349, 60-72.

Olas B., 2020. Honey and its phenolic compounds as an effective natural medicine for cardiovascular diseases in humans? Nutrients 12, 283-296.

PyRZYNSKA K., BiEsaga M., 2009. Analysis of phenolic acids and flavonoids in honey. Trends Analyt. Chem. 28, 893-902.

SAK-BOSNAR M., SAKAČ N., 2012. Direct potentiometric determination of diastase activity in honey. Food Chem. 135, 827-831.

SANTOS-BUElgA C., GONZÁlEZ-PARAMÁS A., M. 2017. Chemical composition of honey [W:] Bee products - chemical and biological properties. ALVAREZ-SUAREZ J. M. (red.). Springer International Publishing AG, Nowy Jork, 43-83.

SCHAFTENAAR F., FRODERMANN V., KUIPER J., LUTGENS E., 2016. Atherosclerosis: the interplay between lipids and immune cells. Curr. Opin. Lipidol. 27, 209-215.

TORNUK F., KARAMAN S., OZTURK I., TOKER O. S., TASTEMUR B., SAgDIC O., DOGan M., KaYACIER A., 2013. Quality characterization of artisanal and retail Turkish blossom honeys: determination of physiochemical, microbiological, bioactive prosperities and aroma profile. Industr. Crops Products 46, 124-131.

WALlace T. C., 2011. Anthocyanins in cardiovascular disease. Adv. Nutrit. 2, 1-7.

YAGHOOBI N., Al-Waili N., GHAYOUR-MOBARHAN M., PARIZADEH S. M. R., ABASALTI Z., YAGHOOBI Z., Yaghoobi F., Esmaeili H., Kazemi-BaJeSTANI S. M. R., AGHASIZADEH R., SAlOOM K. Y., FERNS G. A. A., 2008. Natural honey and cardiovascular risk factors; effects on blood glucose, cholesterol, triacylglycerole, CRP and body weight compared with sucrose. Scient. World J. 8, 463-469.

ZIÓŁKOWSKI M., KUBICA A., SINKIEWICZ W., MACIEJEWSKI J., 2009. Zmniejszanie umieralności na chorobe niedokrwienna serca $w$ Polsce - sukces terapii czy prozdrowotnego stylu życia? Folia Cardiologica Excerpta 4, 265-272. 
KOSMOS Vol. 70, 1, 115-119, 2021

\author{
Monika Frontczak, Beata Olas
}

Department of General Biochemistry, Faculty of Biology and Environmental Protection, University of Lodz, $141 / 143$ Pomorska Str., 90-236 Lodz, E-mail: frontczak.m@wp.pl

\title{
HONEY AND ITS CHEMICAL COMPONENTS; ROLE IN THE PREVENTION AND TREATMENT OF
} CARDIOVASCULAR DISEASES

\section{Summary}

Honey is a sweet natural product made by bees. Its composition depends on many factors, but the dominant sugars are still glucose and fructose, which are responsible for its physicochemical properties. It is also a rich source of phenolic compounds that have a beneficial effect on health. It should only be used as a supplement to a balanced diet, which plays an important role in preventing cardiovascular disease. Depending on the type of honey, its ingredients influence various parameters responsible for developing cardiovascular diseases.

Key words: cardiovascular system, chemical composition, honey 